WOLFGANG MAENNIG / MARKUS WILHELM

BECOMING (UN)EMPLOYED AND LIFE SATISFACTION: ASYMMETRIC EFFECTS AND POTENTIAL OMITTED VARIABLE BIAS IN EMPIRICALHAPPINESS STUDIES

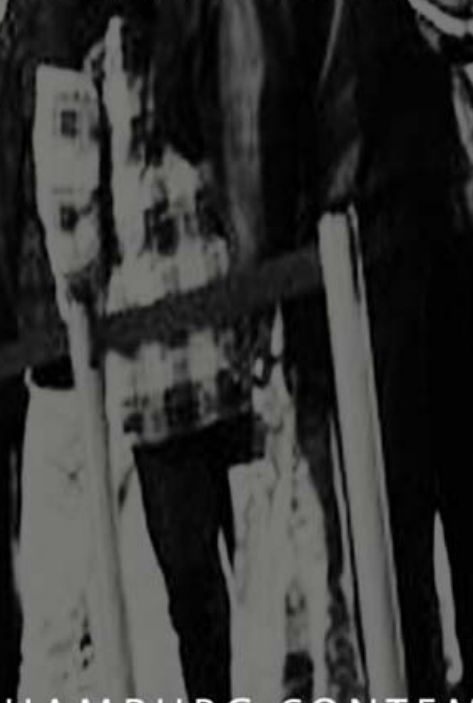

HAMBURG CONTEMPORARY

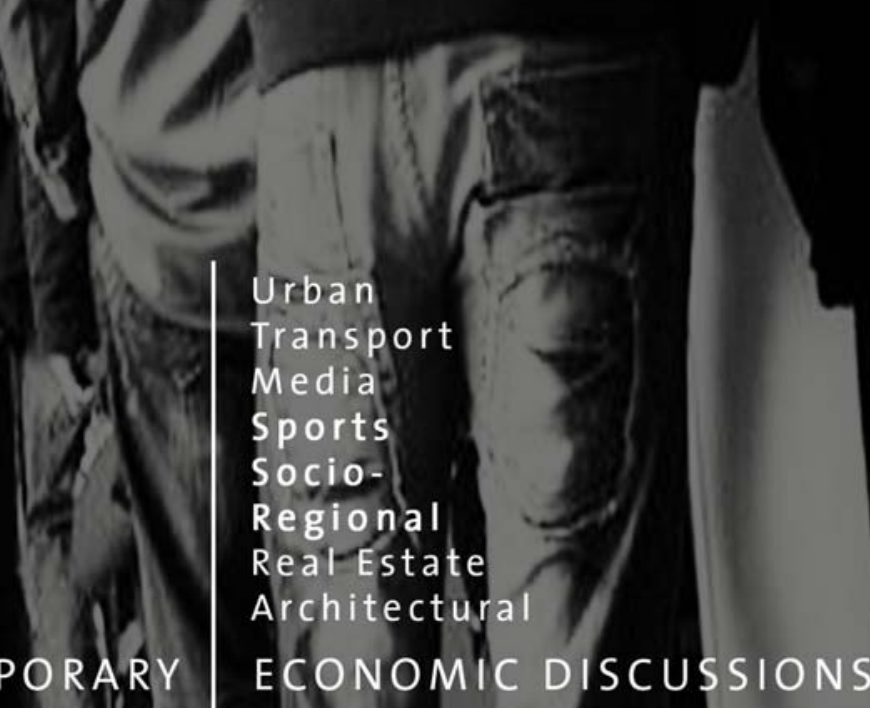

No. 41 
Hamburg Contemporary Economic Discussions

University of Hamburg

Faculty Economics and Social Science

Chair for Economic Policy

Von-Melle-Park 5

D-20146 Hamburg | Germany

Tel $+494042838-4622$

$\mathrm{Fax}+494042838-6251$

http://www.uni-hamburg.de/economicpolicy/

Editor: Wolfgang Maennig

Wolfgang Maennig

University of Hamburg

Faculty Economics and Social Science

Chair for Economic Policy

Von-Melle-Park 5

D-20146 Hamburg | Germany

Tel $+494042838-4622$

Fax $+494042838-6251$

wolfgang.maennig@wiso.uni-hamburg.de

Markus Wilhelm

University of Hamburg

Faculty Economics and Social Science

Chair for Economic Policy

Von-Melle-Park 5

D-20146 Hamburg | Germany

Tel $+494042838-5569$

Fax $+494042838-6251$

markus.wilhelm@wiso.uni-hamburg.de

ISSN 1865 - 2441 (Print)

ISSN 1865 - 7133 (Online)

ISBN $978-3-940369-96-3$ (Print)

ISBN $978-3-940369-97$ - o (Online) 


\title{
Becoming (Un)employed and Life Satisfaction: Asymmetric Effects and Potential Omitted Variable Bias in Empirical Happiness Studies
}

\begin{abstract}
Becoming unemployed has negative effects on life satisfaction; a transition from unemployment to employment, however, has stronger positive effects in absolute terms. The asymmetry of the non-pecuniary effect indicates a potential "omitted variable bias" in previous empirical happiness studies.

Key words: Happiness; Life Satisfaction; Asymmetric Effect; Labour Status; Employment; Unemployment JEL classification:I31, J01, Z13
\end{abstract}

Revised Version: December 2011

\section{Introduction}

The significantly negative effects of "involuntary" loss of one's job on happiness have been documented multiple times. ${ }^{1}$ This study challenges the usual implicit assumption that a transition from employment to unemployment and the transition from unemployment to employment have effects on happiness of the same absolute size, as supported by descriptive statistics of e.g. Winkelmann and Winkelmann (1998) or Grün et al. (2010). Our parametric analyses, which indicate an asymmetry, also control for changes in income in order to isolate potential pecuniary and non-pecuniary costs. We also control for other usual determinants as well as for gender-specific differences (Winkelmann and Winkelmann, 1995).

\footnotetext{
${ }^{1}$ Cf. Blanchflower and Oswald (2004), Powdthavee (2009) and Stutzer (2004).
} 
To operationalise happiness, we apply the single-item measurement of the "Socio-Economic Panel" ${ }^{\prime 2}$ and follow the trends of most of the literature, which interprets the general life satisfaction as a separately measurable category (Diener et al., 1999) and assumes that individuals are best placed to judge their "happiness" (Stutzer and Frey, 2010).

\section{Data and Empirical Strategy}

We use the LONG Beta-Version 2010 of the "Socio-Economic Panel (SOEP)" for the following analysis, a population-representative panel survey conducted in Germany. ${ }^{3}$

The primary data set consists of fourteen transitions (1994 to 1995 and 2007 to 2008). ${ }^{4}$ For the respective starting year, hereinafter designated as $t$, only such entities have been selected as were reported as either in full-time employment or unemployed both at the start of the survey and a year later (hereinafter " $t+1$ "). We restrict the analysis to persons aged between 20 and 65 .

We generate as an endogenous variable $\triangle$ HAPP the annual change in the SOEP variable "general life satisfaction", which ranges from 0 ("completely dissatisfied") to 10 ("completely satisfied"). By differentiating, a range of values arises from -10 to +10 (Grün et al., 2010).

We establish our estimates using a pooled cross-section, controlling for different sample sizes in the SOEP by means of longitudinal and cross-sectional weighting. Against the background of the single-peaked distribution of the endogenous var-

\footnotetext{
${ }^{2}$ The question is: "In conclusion, we would like to ask you about your satisfaction with your life in general. Please answer according to following scale: 0 means "completely dissatisfied", 10 means "completely satisfied". How satisfied are you with your life, all things considered?", http://panel.gsoep.de/soepinfo2009/

${ }^{3}$ See: http://www.diw.de/en/diw_02.c.238121.en/changes_in_the_soep_data_set.html

${ }^{4}$ The analysis is for the period 1994 to 2008 , because this is the only period where all necessary variables are available.

${ }^{5}$ For both points in time, therefore, people without jobs, part-time workers and the self-employed have been excluded.
} 
iable, we estimate OLS models like most of the relevant studies (Ferrer-i-Carbonell and Frijters, 2004). To test the robustness of the estimates, we use "ordered logit estimates".

The set of exogenous variables includes initially the variables frequently tested as being significant for life satisfaction, such as household income, health, number of children and partnership (Stutzer, 2004), which are used for changes in the same way as the endogenous variable. ${ }^{6}$ We also control for changes in uncertainties about the future with the variables "own and overall economic situation".

The operationalisation of the variable "change in employment status" between the periods $\mathrm{t}$ and $\mathrm{t}+1$ yields four manifestations Employed - Employed, Unemployed - Unemployed, Employed $\rightarrow$ Unemployed and Unemployed $\rightarrow$ Employed, with the latter two being at the centre of this study. The reference category is Employed-Employed.

\section{$3 \quad$ Results}

Figure 1 shows the distribution of change in general life satisfaction at the transition from $t$ to $t+1$ for the four types of employment status. The distributions of changes in life satisfaction of the subpopulations of Employed - Employed and Unemployed - Unemployed are relatively symmetrical around zero, although the continuously employed exhibit significantly less change in their life satisfaction than the continuously unemployed. Among the continuously unemployed, there are both more positive and more negative changes in life satisfaction.

The transition from employment into unemployment is associated with a rightskewed distribution ( $v=-0.264$ ), that is, with more (probability) mass in the negative range. People who move from unemployment to full-time employment are characterised by a left-skewed distribution with increased mass in the positive range $(v=0.185)$.

\footnotetext{
${ }^{6}$ Concerning changes in household income, the equivalence-weighted monthly net household income in $\mathrm{t}$ is compared to that in $\mathrm{t}+1$, and the growth rate is calculated.
} 
Fig. 1 Change in Life Satisfaction by Labour Status. Pooled Cross-Section, 1994 to 2008, With Two Transitions Each.

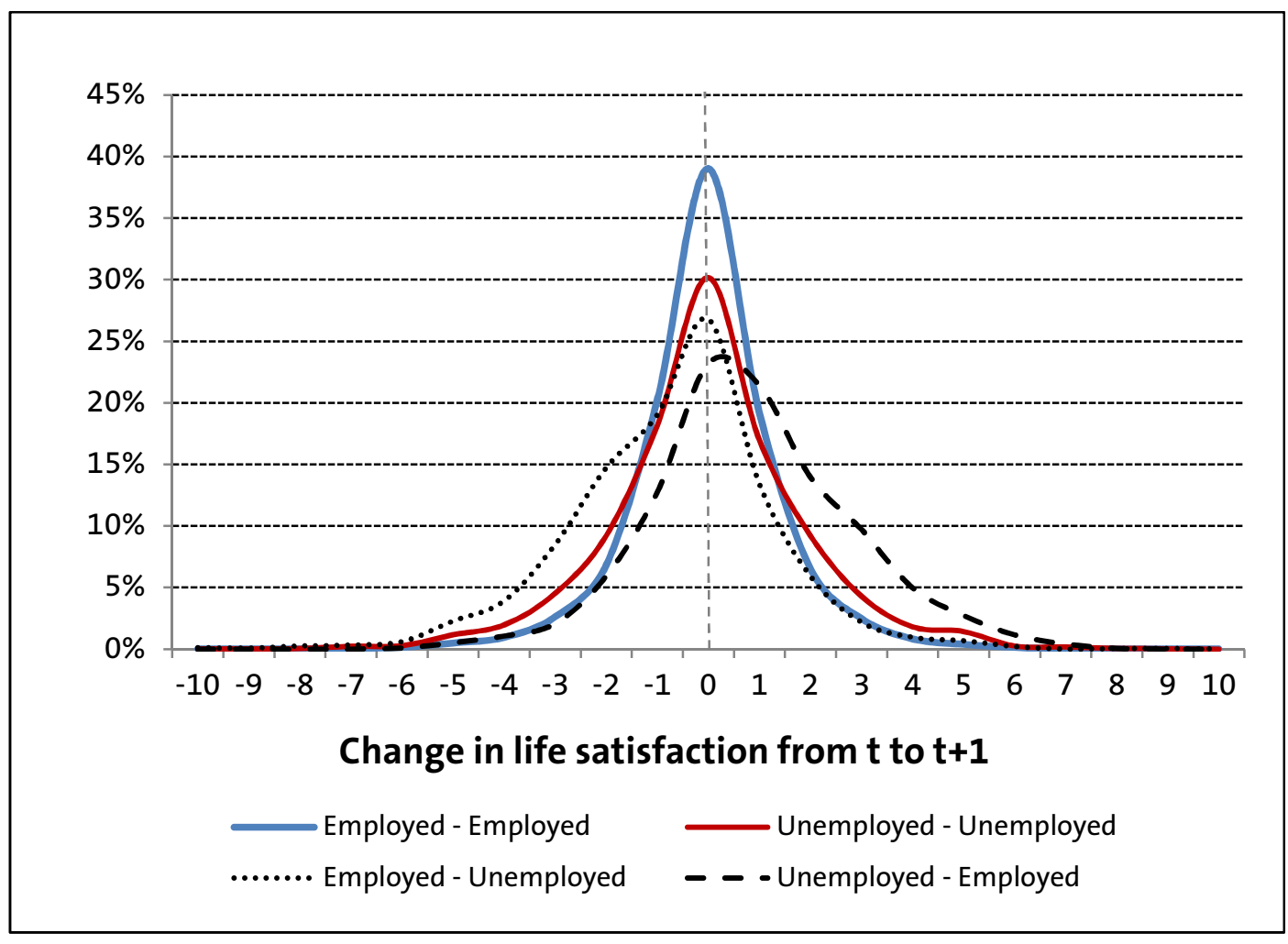

Source: $\quad$ Own analysis, calculation and illustration, LONG Beta-Version SOEP (2010).

Table 1 summarises the regression results. Our estimates on the influence of variables not in the foreground are consistent with results from other studies. Thus, health has a significantly positive impact on life satisfaction (Knabe and Rätzel, 2010). The influence of marital status or non-marital unions shows significant effects (Ferrer-i-Carbonell and Frijters, 2004). We found no significant effect on happiness resulting from the number of children, which, at least, matches the findings of most of the relevant studies (Luechinger, 2010).

As far as the central object of the study is concerned, the change in employment status, Employed $\rightarrow$ Unemployed, as expected, has a significantly negative effect on life satisfaction $(\beta=-0.554)$, generally confirming the results of most of the other relevant studies. Previously job-seeking individuals who start full-time employment in $\mathrm{t}+1$ (Unemployed $\rightarrow$ Employed with $\beta=0.719$ ) exhibit significantly positive effects in terms of changes in their life satisfaction. In absolute terms the latter effect is significantly larger, constituting an asymmetry between leaving 
and joining the labour market. ${ }^{7}$ This effect is the non-pecuniary effect of the transition to unemployment or employment, because the study controls for the (significant) influence of net household income.

Model B tests whether changes in income also have asymmetric effects on happiness, but we do not find such evidence. ${ }^{8}$ The asymmetric non-pecuniary effects of the change of employment status (measured by the difference of the absolute size of the coefficients of the change in employment status) remain fully intact.

Furthermore we test for the changes in the (perceived) "own economic situation" and "overall economic situation". Both variables are significant, the first determinant being more influential.

Model C tests for gender-specific differences. First, it should be noted that a positive change in health has a slightly significant larger positive effect for women. Finding a partner is significantly more positive for women; however, no significant differences were found in connection with the loss of a partner. We did not find gender-specific differences for the other variables (not reported in Table 1).

In the gender-specific version of the "ordered logit estimation", the asymmetric effect between Employment $\rightarrow$ Unemployment and Unemployment $\rightarrow$ Employment on happiness remains exclusively for women.

\footnotetext{
${ }^{7}$ For the asymmetric effects of the OLS models A, B and C, see the significant f-tests between employed-unemployed and unemployed-employed (see Table 1).

${ }^{8}$ The f-tests in the OLS models B and C between the income associated with the transition to unemployment and the transition to employment show no significant results.
} 


\section{Table 1: Determinants of Change of Happiness; Regression Results}

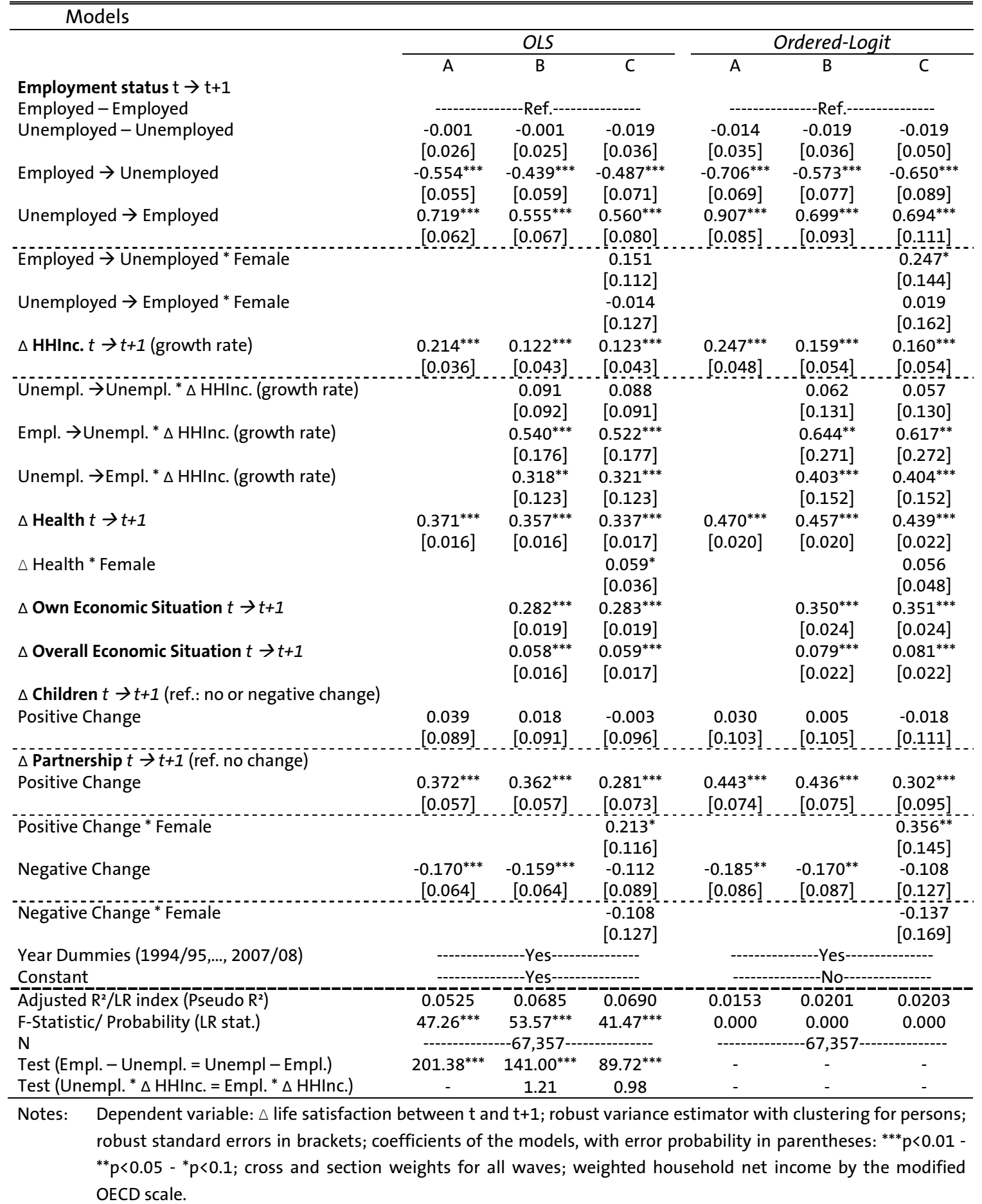

Source: Own analysis, calculation and illustration, LONG Beta-Version SOEP, 2010. 
We note that the loss of a job can be associated with significantly smaller nonpecuniary losses in life satisfaction than the corresponding gains realised when moving from unemployment to employment. Empirical research which does not control for such asymmetries has a potential omitted variable bias, with the consequence of possibly underestimating the effects of Unemployment $\rightarrow$ Employment on life satisfaction. 


\section{Literature}

BLANCHFLOWER, D. / OSWALD, A. (2004), Well-being over time in Britain and the USA. Journal of Public Economics 88, 1359-1386.

DIENER, E. / SUH, E.M. / LUCAS, E.R. / SMITH, H.L. (1999), Subjective well-being: Three decades of progress. Psychological Bulletin 125 (2), 276-302.

FERRER-I-CARBONELL, A. / FRIJTERS, P. (2004), How important is Methodology for the estimates of the determinants of Happiness? Economic Journal 114, 641-659.

GRÜN, C. / HAUSER, W. / RHEIN, T. (2010), Is Any Job Better than No Job? Life Satisfaction and Re-employment. Journal of Labor Research 31 (3), 285-306.

KNABE, A. / RÄTZEL, S. (2010), Income, happiness, and the disutility of labour. Economics Letters 107 (1), 77-79.

LUECHINGER, S. / MEIER, S. / STUTZER, A. (2010), Why Does Unemployment Hurt the Employed?: Evidence from the Life Satisfaction Gap Between the Public and the Private Sector. Journal of Human Resources 45 (4), 998-1045.

POWDTHAVEE, N. (2009), How much does money really matter? Estimating the causal effects of income on happiness. Empirical Economics 39 (1), 77-92.

STUTZER, A. (2004), The Role of Income Aspirations in Individual Happiness. Journal of Economic Behavior \& Organization 54 (1), 89-109.

STUTZER, A. / FREY, B.S. (2010), Recent Advances in the Economics of Individual Subjective Well-Being. Social Research: An International Quarterly 77 (2), 679-714.

WINKELMANN, L. / WINKELMANN, R. (1995), Happiness and Unemployment: A Panel Data Analysis for Germany. Konjunkturpolitik 41 (4), 293-307.

WINKELMANN, L. / WINKELMANN, R. (1998), Why Are The Unemployed So Unhappy? Evidence from Panel Data. Economica 65, 1-15. 


\section{Hamburg Contemporary Economic Discussions}

(Download: http://www.uni-hamburg.de/economicpolicy/discussions.html)

41

40
MAENNIG, W. / WILHELM, M.: Becoming (un)employed and life satisfaction: Asymmetric effects and potential omitted variable bias in empirical happiness studies

MAENNIG, W.: Monument Protection and Zoning in Germany: Regulations and Public Support from an International Perspective

BRANDT, S. / MAENNIG, W.: Perceived Externalities of Cell Phone Base Stations - The Case of Property Prices in Hamburg, Germany

MAENNIG, W. / STOBERNACK, M.: Do Men Slow Down Faster than Women?, 2010

DU PLESSIS, S. A. / MAENNIG, W.: The 2010 World Cup Highfrequency Data Economics: Effects on International Awareness and (Self-defeating) Tourism, 2010

BISCHOFF, O.: Explaining Regional Variation in Equilibrium Real Estate Prices and Income, 2010.

FEDDERSEN, A. / MAENNIG, W.: Mega-Events and Sectoral Employment: The Case of the 1996 Olympic Games, 2010.

FISCHER, J.A.V. / SOUSA-POZA, A.: The Impact of Institutions on Firms Rejuvenation Policies: Early Retirement with Severance Pay versus Simple Lay-Off. A Cross-European Analysis, 2010.

FEDDERSEN, A. / MAENNIG, W.: Sectoral Labor Market Effects of the 2006 FIFA World Cup, 2010.

AHLFELDT, G.: Blessing or curse? Appreciation, Amenities, and Resistance around the Berlin "Mediaspree", 2010.

FALCH, T. / FISCHER, J.A.V.: Public Sector Decentralization and School Performance: International Evidence, 2010.

AHLFELDT, G. / MAENNIG, W. / ÖLSCHLÄGER, M.: Lifestyles and Preferences for (Public) Goods: Professional Football in Munich, 2009.

FEDDERSEN, A. / JACOBSEN, S. / MAENNIG, W.: Sports Heroes and Mass Sports Participation - The (Double) Paradox of the "German Tennis Boom", 2009.

AHLFELDT, G. / MAENNIG, W. / OSTERHEIDER, T.: Regional and sectoral effects of a common monetary policy: evidence from Euro Referenda in Denmark and Sweden, 2009. 


\section{Hamburg Contemporary Economic Discussions}

(Download: http://www.uni-hamburg.de/economicpolicy/discussions.html)

BJØRNSKOV , C. / DREHER, A. / FISCHER, J.A.V. / SCHNELLENBACH, J.: On the Relation Between Income Inequality and Happiness: Do Fairness Perceptions Matter?, 2009.

AHLFELDT, G. I MAENNIG, W.: Impact of Non-Smoking Ordinances on Hospitality Revenues: The Case of Germany, 2009.

FEDDERSEN, A. / MAENNIG, W.: Wage and Employment Effects of the Olympic Games in Atlanta 1996 Reconsidered, 2009.

AHLFELDT, G. / FRANKE, B. / MAENNIG, W.: Terrorism and the Regional and Religious Risk Perception of Foreigners: The Case of German Tourists, 2009.

AHLFELDT, G. / WENDLAND, N.: Fifty Years of Urban Accessibility: The Impact of Urban Railway Network on the Land Gradient in Industrializing Berlin, 2008.

AHLFELDT, G. / FEDDERSEN, A.: Determinants of Spatial Weights in Spatial Wage Equations: A Sensitivity Analysis, 2008.

MAENNIG, W. / ALLERMS, S.: South Africa 2010: Economic Scope and Limits, 2008.

MAENNIG, W. / WELLBROCK, C.-M.: Sozio-ökonomische Schätzungen Olympischer Medaillengewinne: Analyse-, Prognose- und Benchmarkmöglichkeiten, 2008.

AHLFELDT, G.: The Train has Left the Station: Real Estate Price Effects of Mainline Realignment in Berlin, 2008.

MAENNIG, W. / PORSCHE, M.: The Feel-good Effect at Mega Sport Events - Recommendations for Public and Private Administration Informed by the Experience of the FIFA World Cup 2006, 2008.

AHLFELDT, G. / MAENNIG, W.: Monumental Protection: Internal and External Price Effects, 2008.

FEDDERSEN, A. / GRÖTZINGER, A. / MAENNIG, W.: New Stadia and Regional Economic Development - Evidence from FIFA World Cup 2006 Stadia, 2008.

AHLFELDT, G. / FEDDERSEN, A.: Geography of a Sports Metropolis, 2007.

FEDDERSEN, A. / MAENNIG, W.: Arenas vs. Multifunctional Stadia Which Do Spectators Prefer?, 2007. 


\section{Hamburg Contemporary Economic Discussions}

(Download: http://www.uni-hamburg.de/economicpolicy/discussions.html)

13
AHLFELDT, G.: A New Central Station for a Unified City: Predicting Impact on Property Prices for Urban Railway Network Extension, 2007.

AHLFELDT, G.: If Alonso was Right: Accessibility as Determinant for Attractiveness of Urban Location, 2007.

AHLFELDT, G., MAENNIG, W.: Assessing External Effects of City Airports: Land Values in Berlin, 2007.

MAENNIG, W.: One Year Later: A Re-appraisal of the Economics of the 2006 Soccer World Cup, 2007.

HAGN, F. / MAENNIG, W.: Employment Effects of the World Cup 1974 in Germany.

HAGN, F. / MAENNIG W.: Labour Market Effects of the 2006 Soccer World Cup in Germany, 2007.

JASMAND, S. / MAENNIG, W.: Regional Income and Employment Effects of the 1972 Munich Olympic Summer Games, 2007.

DUST, L. / MAENNIG, W.: Shrinking and Growing Metropolitan Areas-Asymmetric Real Estate Price Reactions? The Case of German Single-family Houses, 2007.

HEYNE, M. / MAENNIG, W. / SUESSMUTH, B.: Mega-sporting Events as Experience Goods, 2007.

DU PLESSIS, S. / MAENNIG, W.: World Cup 2010: South African Economic Perspectives and Policy Challenges Informed by the Experience of Germany 2006, 2007.

AHLFELDT, G. / MAENNIG, W.: The Impact of Sports Arenas on Land Values: Evidence from Berlin, 2007.

FEDDERSEN, A. / MAENNIG, W. / ZIMMERMANN, P.: How to Win the Olympic Games - The Empirics of Key Success Factors of Olympic Bids, 2007.

AHLFELDT, G. I MAENNIG, W.: The Role of Architecture on Urban Revitalization: The Case of "Olympic Arenas" in Berlin-Prenzlauer Berg, 2007. 


\section{Hamburg Contemporary Economic Discussions}

(Download: http://www.uni-hamburg.de/economicpolicy/discussions.html)

04/2006 MAENNIG, W. I SCHWARTHOFF, F.: Stadium Architecture and Regional Economic Development: International Experience and the Plans of Durban, October 2006.

03/2006 FEDDERSEN, A. / VÖPEL, H.: Staatliche Hilfen für Profifußballclubs in finanziellen Notlagen? - Die Kommunen im Konflikt zwischen Imageeffekten und Moral-Hazard-Problemen, September 2006.

02/2006 FEDDERSEN, A.: Measuring Between-season Competitive Balance with Markov Chains, July 2006.

01/2006 FEDDERSEN, A.: Economic Consequences of the UEFA Champions League for National Championships - The Case of Germany, May 2006.

04/2005 BUETTNER, N. / MAENNIG, W. / MENSSEN, M.: Zur Ableitung einfacher Multiplikatoren für die Planung von Infrastrukturkosten anhand der Aufwendungen für Sportstätten - eine Untersuchung anhand der Fußball-WM 2006, May 2005.

03/2005 SIEVERS, T.: A Vector-based Approach to Modeling Knowledge in Economics, February 2005.

02/2005 SIEVERS, T.: Information-driven Clustering - An Alternative to the Knowledge Spillover Story, February 2005.

01/2005 FEDDERSEN, A. I MAENNIG, W.: Trends in Competitive Balance: Is there Evidence for Growing Imbalance in Professional Sport Leagues?, January 2005. 


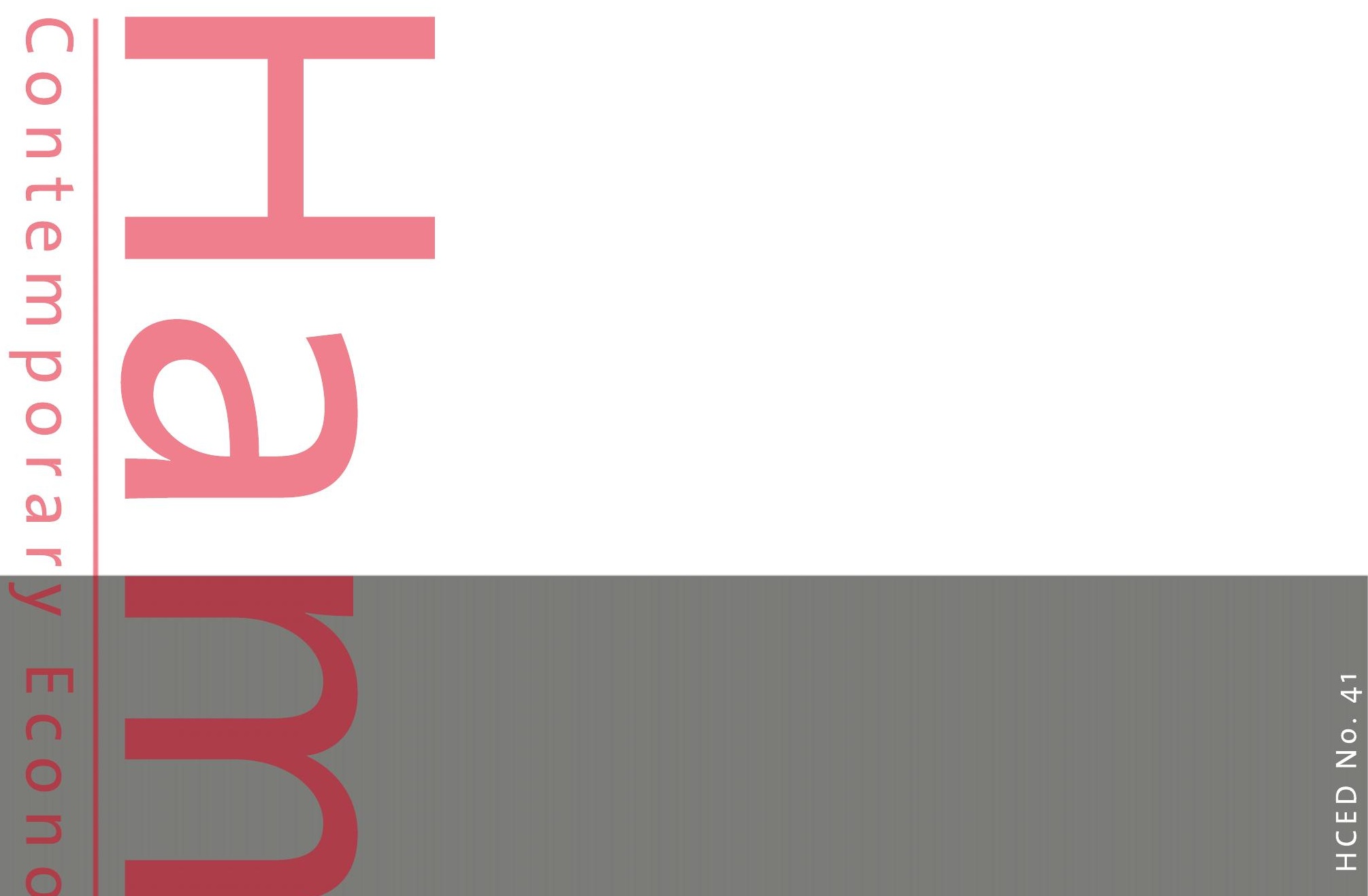

